\title{
Estimation of Nitrogen Uptake Rate of Small Zooplankton Using ${ }^{15} \mathrm{~N}$ tracer
}

\author{
Tadafumi IcHIKAWA, Takahito YoshIokA, Eitaro WADA \\ and Hidetake HaYASHI
}

\begin{abstract}
The uptake rate of nitrogen by freshwater zooplankton was measured by use of a ${ }^{15} \mathrm{~N}$ tracer technique under experimental conditions. To detect the low quantities of excess ${ }^{15} \mathrm{~N}$ in less than several hundreds of small zooplankton individuals (as small as $5 \mu \mathrm{gN}$ ), an isotope dilution technique was adopted using a ratio mass spectrometer. The analytical differences between natural ${ }^{15} \mathrm{~N}$ abundance method and result obtained by this technique were -0.00210 to $+0.00113{ }^{15} \mathrm{~N}$ atom \% (mean \pm S.D. $=0.00048 \pm$ $0.0010{ }^{15} \mathrm{~N}$ atom \%). We obtained uptake rates of $8.5 \times 10^{-8} \mathrm{mg}$ atom $-\mathrm{N} \cdot$ indiv. $^{-1} \cdot \mathrm{day}^{-1}$ by Kellicottia longispina in Lake Nakatsuna and $4.2 \times 10^{-7}$ by Keratella quadrata in Lake Suwa. Net production rates calculated from the data of the uptake rates, carbon contents and nitrogen contents were $5.1 \times 10^{-6} \mathrm{mgC} \cdot$ indiv. $^{-1} \cdot$ day $^{-1}$ for $K$. longispina and $2.5 \times 10^{-5} \mathrm{mgC} \cdot$ indiv. $^{-1} \cdot$ day $^{-1}$ for $K$. quadrata. Using a combination of the ratio mass spectrometer and the ${ }^{15} \mathrm{~N}$ tracer experiment, the nitrogen uptake rates from nutrient salt to phytoplankton and further to zooplankton can be detected directly at the same time and on the same space scale.
\end{abstract}

Key words: ${ }^{15} \mathrm{~N}$ tracer technique; zooplankton; nitrogen uptake rate; lacustrine ecosystems

\section{Introduction}

Small zooplankton, such as rotifers, have key roles as secondary producer in lacustrine ecosystems. Feeding habits of zooplankton have been investigated with various methods, such as in situ experiments using radio isotopes, as tracers (HANEY, 1973; LAMPERT, 1975; LAMPERT and Gabriel, 1984; Gilbert and Bogdan, 1985; Wallace and StarkWEather, 1985; BJøRNSEN, 1986; Bosselmann and Riemann, 1986). However, our knowledge of and information on the nitrogen flow through small zooplankton are still limited. Up to now nitrogen uptake kinetics of small zooplankton have been determined indirectly by the conversion from dry weight or carbon to nitrogen (WATERS, 1977; FASHAM et al., 1990). Although phytoplankton have been an object of study using a stable nitrogen isotope tracer (WADA et al., 1977; TAKAHASH $e t$ al., 1981; KANDA et al., 1985), only a few experiments have been carried out to determine the nitrogen flow through small zooplankton (OTSUKI et al., 1985). This is partly due to technical difficulties in the detection of very small quantities of tracers, such as ${ }^{15} \mathrm{~N}$, transferred to small zooplankton species.

The ratio-mass spectro-analysis allows the detection of very small amounts of natural stable isotopes such as ${ }^{15} \mathrm{~N}$, and may be applicable to a micro scale tracer experiment (WADA et al., 1977). Nitrogen flowing through zooplankton can be measured directly,using a combination of the mass spectro-analysis and the ${ }^{15} \mathrm{~N}$ tracer technique. This technique allows us to show the nitrogen transferred from phytoplankton to zooplankton simultaneously and within the same system. 
This paper describes the experimental procedure of the ${ }^{15} \mathrm{~N}$ analysis, including the isotope dilution with nitrogen carrier, and the results of experiments carried out with samples originating from two Japanese lakes.

\section{Materials and methods}

\section{2-1. Tracer experiment}

Lake water was collected with a column sampler $(\phi 40 \mathrm{~mm} \times 200 \mathrm{~cm}$, about 2 liters in volume) from 0 to $4 \mathrm{~m}$ depth in Lake Nakatsuna (max. depth $12.0 \mathrm{~m}$, surface area $0.14 \mathrm{~km}^{2}$ ) on 12 May 1987, and in Lake Suwa $(6.3 \mathrm{~m}, 13.3$ $\mathrm{km}^{2}$ ) on 30 April 1987. Both lakes are located in the central part of Honshu, Japan. Zooplankton were collected by vertical tows with plankton nets of 40 or $98 \mu \mathrm{m}$ mesh size.

Water of Lake Nakatsuna, collected on 12 May 1987 was put in glass bottles (10 liters each in volume) immediately after sampling without any filtration. One bottle was used as a control (time $0 \mathrm{hr}$ ), while the other bottles were enriched with $9.97 \mu \mathrm{g}$ atom- $\mathrm{N}$ of $\left({ }^{15} \mathrm{NH}_{4}\right)_{2} \mathrm{SO}_{4}$ (atomic percentage of ${ }^{15} \mathrm{~N}=50.47 \%$ ), and incubated in a water bath at the same temperature as that of the sampling depth $\left(7^{\circ} \mathrm{C}\right)$ under a $13 \mathrm{hr}$ light (3,500 lux) and $11 \mathrm{hr}$ dark photocycle. After incubation for 24,48 and $96 \mathrm{hr}$, one of these bottles was set aside for ${ }^{15} \mathrm{~N}$ analyses of particulate organic matter (POM) and zooplankton, as shown in Figure 1. Appropriate amounts of the water samples (200 to $1000 \mathrm{ml}$ ) were filtered through precombusted $\left(450{ }^{\circ} \mathrm{C}, 1\right.$ $\mathrm{hr}$ ) Whatman GF/C glass-fiber filters. These filters were used to measure the organic carbon and nitrogen contents of POM, and the filtered water samples were used for ammonium-N analysis. From the remaining water samples, POM and zooplankton were fractionated with $20,40,64$ and $98 \mu \mathrm{m}$ mesh sized nets to differentiate the nitrogen uptake rates of each size fraction. Zooplankton from the 64 to $98 \mu \mathrm{m}$ and $>98 \mu \mathrm{m}$ fractions were further sorted to species level by using glass capillary under a stereo-microscope. These plankton samples were collected on precombusted $\left(450{ }^{\circ} \mathrm{C}, 1 \mathrm{hr}\right.$ ) Whatman GF/F glass-fiber filters, and washed with a small amount of $0.005 \mathrm{~N} \mathrm{HCI}$ and deion-

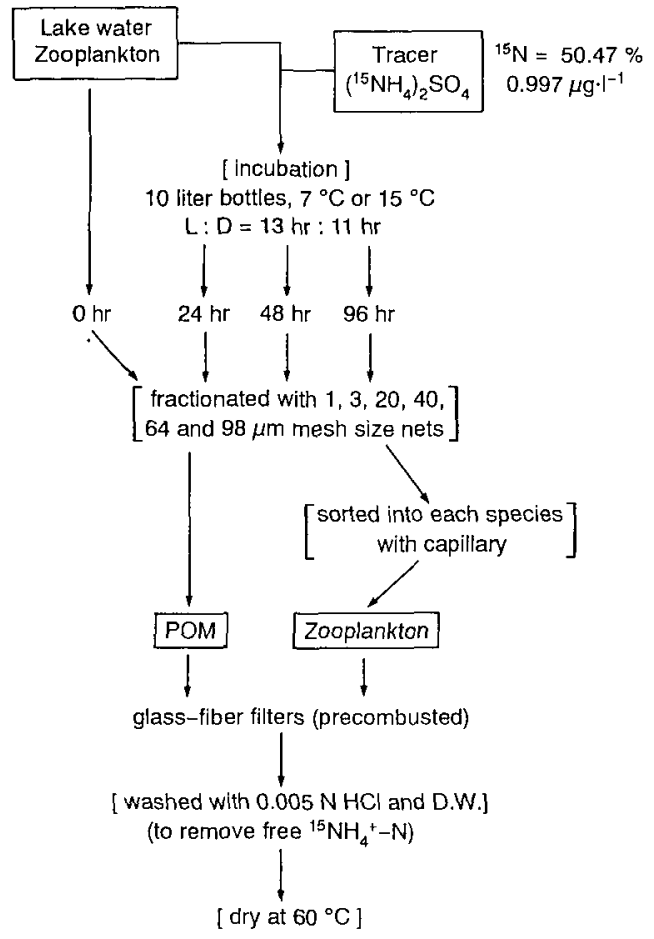

Fig. 1. Schematic presentation of tracer experiment. Time course of ${ }^{15} \mathrm{~N}$ tracer from ${ }^{15} \mathrm{NH}_{4}{ }^{+}-\mathrm{N}$ into organic matter.

ized water to remove free ${ }^{15} \mathrm{NH}_{4}{ }^{+}-\mathrm{N}$, before being dried at $60{ }^{\circ} \mathrm{C}$. They were weighed and kept in a desiccator. ${ }^{15} \mathrm{~N}$ contents were analyzed with mass-spectrometry as described below. Organic carbon and nitrogen contents were determined with a Yanaco MT-2 CHN analyzer. Ammonium- $\mathrm{N}$ was analyzed using a Technicon Auto-Analyzer II (TECHNICON INDUSTRIAL METHODOLOGY, 1974).

Similar experiments were carried out on 30 April 1987 with samples from Lake Suwa. The lake water samples were incubated outside the Suwa Hydrobiological Station, Shinshu University at about $15{ }^{\circ} \mathrm{C}$ which corresponds to in situ temperature.

\section{2-2. Determination of nitrogen isotope ratio}

To each of the samples for nitrogen analysis L-alanine $(2.00 \mathrm{mg}$, Kokusan Chemical Co., Inc.) was added as a nitrogen carrier. Organic nitrogen of the sample enriched with alanine was converted to $\mathrm{N}_{2}$ gas by the combustion 
method (Minagawa et al., 1984). After cryogenic purification in a vacuum line, the $\mathrm{N}_{2}$ gas was introduced into a Hitachi RMU-6R mass spectrometer fitted with double collector and double inlet system for ratiometry.

The nitrogen isotope ratio was presented as permill deviation from standard, as defined by the following equation:

$$
\delta^{15} \mathrm{~N}(\%)=\left(\frac{R_{\text {sample }}}{R_{\text {std }}}-1\right) \times 1000,
$$

where $R$ denotes ${ }^{15} \mathrm{~N} /{ }^{14} \mathrm{~N}$. The atmospheric nitrogen was used as a standard. $R_{\text {std }}$ value is $0.3663{ }^{15} \mathrm{~N}$ atom $\%$. The analytical error of the mass spectrometric measurement of $\delta^{15} \mathrm{~N}$ value itself was found to be less than $\pm 0.2 \%$ (S. D.), or $\pm 0.00007{ }^{15} \mathrm{~N}$ atom $\%$ (S. D.), In our method, in which alanine was added, the equation (1) was reformulated as follows,

$$
\delta^{15} \mathrm{~N}_{\mathrm{obs}}(\%)=\left(\frac{\mathrm{R}_{\text {(sample+alanine) }}}{R_{\text {std }}}-1\right) \times 1000,
$$

where $\delta^{15} \mathrm{~N}_{\mathrm{obs}}$ is the nitrogen isotope ratio of the sample with alanine. Therefore the $\delta$ value for the sample nitrogen $\left(\delta^{15} \mathrm{~N}_{\mathrm{s}}\right)$ was calculated by the following equation.

$\delta^{15} \mathrm{~N}_{\mathrm{s}}(\% \mathrm{o})=\frac{\left(\mathrm{N}_{\mathrm{s}}+\mathrm{N}_{\mathrm{a}}\right) \delta^{15} \mathrm{~N}_{\mathrm{obs}}-\mathrm{N}_{\mathrm{a}} \cdot \delta^{15} \mathrm{~N}_{\mathrm{a}}}{\mathrm{N}_{\mathrm{s}}}$,

where $\mathrm{N}_{\mathrm{s}}, \mathrm{N}_{\mathrm{a}}$ and $\delta^{15} \mathrm{~N}_{\mathrm{a}}$ are the amounts of nitrogen in the sample, the alanine, and the isotope ratio of alanine, respectively. Since $\mathrm{N}_{\mathrm{s}}$ was not measured directly during the ${ }^{15} \mathrm{~N}$ analysis, it was calculated from the dry weight of samples supplied by isotope measurements and from the nitrogen content in each of the fractions of the samples without incubation $(0 \mathrm{hr}$ samples). The $\delta^{15} \mathrm{~N}_{\mathrm{a}}$ and $\mathrm{N}_{\mathrm{a}}$ are $-5.3 \pm 0.2 \%$ (mean \pm S. D., $n=17$ ) and $0.315 \mathrm{mgN}$ (calculated from the chemical formula of alanine), respectively. The ${ }^{15} \mathrm{~N}$ atom $\%$ in samples was calculated from the $\delta$ value by the following equation.

${ }^{15} \mathrm{~N}$ atom $\%=\frac{R_{\text {std }}\left(\delta^{15} \mathrm{~N}_{\mathrm{s}} / 1000+1\right)}{R_{\text {std }}\left(\delta^{15} \mathrm{~N}_{\mathrm{s}} / 1000+1\right)+1} \times 100,(4)$

The variation caused by the analytical procedure in the determination of ${ }^{15} \mathrm{~N}$ contents of several plankton samples collected from Lake Suwa was examined by comparison between the $\delta^{15} \mathrm{~N}_{\mathrm{s}}$ without incubation $(0 \mathrm{hr}$ samples, alanine was added) and the natural abundance of nitrogen isotope $\left(\delta^{15} \mathrm{~N}\right)$.

\section{Results and discussion}

The results of the comparison between the $\delta^{15} \mathrm{~N}_{\mathrm{s}}$ without incubation and the $\delta^{15} \mathrm{~N}$ for Lake Suwa samples are presented in Table 1. The differences in ${ }^{15} \mathrm{~N}$ contents between $\delta^{15} \mathrm{~N}_{\mathrm{s}}$ and $\delta^{15} \mathrm{~N}$ values were -5.8 to $+3.1 \%$ (mean $\pm \mathrm{S}$. D. $=-1.46 \pm 2.86 \%, n=8$, Table 1 ) beyond the wide range of the taxonomic groups of plank-

Table 1. Comparison of $\delta$ values $(\%)$ and ${ }^{15} \mathrm{~N}$ atom $\%$ with data for natural nitrogen isotope abundance in Lake Suwa. $\Delta$ values are difference between natural abundance and sample with alanine

\begin{tabular}{|c|c|c|c|c|c|c|c|}
\hline \multirow[t]{2}{*}{ Sample Name } & \multirow[t]{2}{*}{ Date } & \multicolumn{2}{|c|}{ Natural abundance } & \multicolumn{2}{|c|}{ After alanine addition } & \multicolumn{2}{|c|}{ Differences } \\
\hline & & $\delta^{15} \mathrm{~N}$ & atom $\%$ & $\delta^{15} \mathrm{~N}$ & atom \% & $\Delta \delta^{15} \mathrm{~N}$ & $\Delta$ atom $\%$ \\
\hline Keratella quadrata & $1987,5.2$ & 7.8 & 0.36783 & 2.0 & 0.36573 & -5.8 & -0.00210 \\
\hline Bosmina fatalis & $1987,6.4$ & 9.3 & 0.36838 & 9.3 & 0.36838 & 0 & 0.00000 \\
\hline Leptodora kindtii & $1987,6.4$ & 13.5 & 0.36991 & 7.9 & 0.36788 & -5.6 & -0.00203 \\
\hline Eodiaptomus japonicus & $1987,6.4$ & 13.2 & 0.36980 & 10.6 & 0.36886 & -2.6 & -0.00094 \\
\hline Cyclops vicinus & $1987,5.2$ & 10.4 & 0.36878 & 13.5 & 0.36991 & 3.1 & 0.00113 \\
\hline Microcystis aemiginosa & $1987,6.4$ & 6.7 & 0.36744 & 7.2 & 0.36762 & 0.5 & 0.00018 \\
\hline POM (1-98 $\mu$ m fraction $)$ & $1987,6.4$ & 7.9 & 0.36787 & 7.0 & 0.36755 & -0.9 & -0.00032 \\
\hline POM (3-10 $\mu$ m fraction) & $1987,6.4$ & 7.5 & 0.36773 & 7.1 & 0.36758 & -0.4 & 0.00025 \\
\hline Mean \pm S. D & - & - & - & - & - & $-1.46 \pm 2.86$ & $-0.00048 \pm 0.00106$ \\
\hline
\end{tabular}
added. 
ton. These differences corresponded to 0.00210 to $+0.00113{ }^{15} \mathrm{~N}$ atom \% $(-0.00048 \pm$ $0.00106{ }^{15} \mathrm{~N}$ atom \%). This variance was in the same range as the data of ${ }^{15} \mathrm{~N}$ analysis which OTsuki (1985) obtained by mass spectrometer, though his samples contained more nitrogen $(>35 \mu \mathrm{gN})$ than ours $(5 \mu \mathrm{gN})$.

The experimental results of Lake Nakatsuna samples are given in Figure 2. In POM samples, the " $1-20 \mu \mathrm{m}$ " fraction mainly consisted of Peridinium sp., some Asterionella sp. and Uroglenopsis americana. The " $20-98 \mu \mathrm{m}$ " fraction consisted principally of Uroglenopsis americana, Asterionella sp. and some zooplankton (nauplii and rotifer). The ${ }^{15} \mathrm{~N}$ atom $\%$ in every POM fraction increased meaning for the first $48 \mathrm{hr}$ (Fig. 2a). The ${ }^{15} \mathrm{~N}$ atom \% in Kellicottia longispina and "Rotifer mix" ( $K$. longispina: Filinia sp.: Keratella quadrata $=4:$ 3: 1 , individual numbers) increased up to $96 \mathrm{hr}$ (Fig. 2b). A chronological difference of the ${ }^{15} \mathrm{~N}$ increase between POM and zooplankton was also obtained by Orsuki et al. (1985). The level of ${ }^{15} \mathrm{~N}$ atom \% of zooplankton was lower than that of POM. Since the nitrogen content of zooplankton was 2 to 3 times higher than POM (Table 2), replacing ${ }^{14} \mathrm{~N}$ in zooplankton bodies with ${ }^{15} \mathrm{~N}$ tracer from phytoplankton may require a longer time than that for phytoplan- kton.

The experimental results of Lake Suwa are Shown in Figure 3. In POM samples, " $1-3 \mu \mathrm{m}$ " and " $3-20 \mu \mathrm{m}$ " fractions mainly consisted of Cyclotella sp.; "24-40 $\mu \mathrm{m}$ " was made up of Asterionella sp. and Cyclotella sp.; "40-100 $\mu \mathrm{m}$ " conisisted of Fragilaria sp., Synedra sp. and some zooplankton (nauplii and small rotifers). The content of ${ }^{15} \mathrm{~N}$ in POM increased during the first $24 \mathrm{hr}$ and decreased thereafter, except for the largest fraction which continued to increase slightly during this period (Fig. 3a). These results are in contrast to those for Lake Nakatsuna. The ${ }^{15} \mathrm{~N}$ atom \% of the smaller POM fraction at $24 \mathrm{hr}$ was higher than that of the larger one.

The increment of ${ }^{15} \mathrm{~N}$ atom \% during the incubation period of the zooplankton fraction of Lake Suwa is shown in Figure 3b. The ${ }^{15} \mathrm{~N}$ atom \% in Keratella quadrata and Brachionus calyciflorus were different at $48 \mathrm{hr}$ from each other. The rate of increase of ${ }^{15} \mathrm{~N}$ of both rotifers declined during the 24 to $48 \mathrm{hr}$, compared with those between 0 and $24 \mathrm{hr}$. These decreases may reflect a reduction of the ${ }^{15} \mathrm{~N}$ atom \% in the POM fraction.

The amount of nitrogen transfer par unit of time (nitrogen uptake rates) of POM and zooplankton fractions are shown in Table 3.
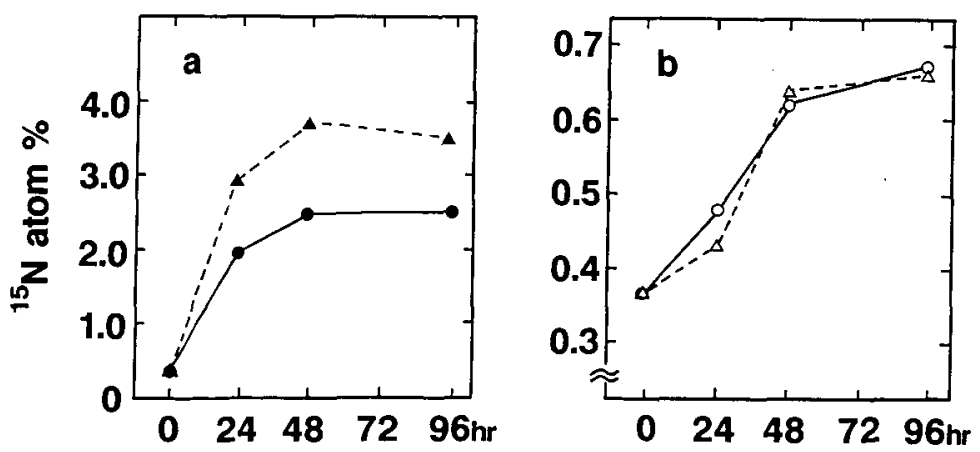

Fig. 2. Changes in ${ }^{15} \mathrm{~N}$ atom \% of POM fractions (a) and zooplankton (b) samples after addition of $\left({ }^{15} \mathrm{NH}_{4}\right)_{2} \mathrm{SO}_{4}$ to Lake Nakatsuna water. In POM samples: "1-20 $\mu \mathrm{m}$ " fraction contained Peridinium sp., some Asterionella sp. and Uroglenopsis americana; "20-98 $\mu \mathrm{m}$ " fraction contained Uroglenopsis americana, Asterionella sp. and some zooplankton. In zooplankton, "Rotifer mix" fraction consisted of Kellicottia longispina, Filinia sp., and Keratella quadrata in ratio of about 4: 3: 1. Symbols: $\Delta, 1-20 \mu \mathrm{m}:-20-98 \mu \mathrm{m}: \bigcirc$, Kellicottia longispina; $\triangle$, "Rotifer mix". 
Table 2. Dry weight, $\mathrm{N}$ content and $\mathrm{C} / \mathrm{N}$ of zooplankton species and POM fractions in Lake Nakatsuna and Lake Suwa.

\begin{tabular}{|c|c|c|c|c|c|}
\hline Sample name & Date & Sampling lake & $\begin{array}{l}\text { Dry weight } \\
\left(\mu \mathrm{g} \cdot \text { indiv }^{-1}\right)\end{array}$ & $\begin{array}{l}\mathrm{N} \text { content } \\
(\%-\mathrm{D} . \mathrm{W} .)\end{array}$ & $\begin{array}{c}\mathrm{C} / \mathrm{N} \\
\text { (weight ratio) }\end{array}$ \\
\hline \multicolumn{6}{|l|}{ Zooplankton } \\
\hline Kellicottia longispina & 1987.5 .12 & Lake Nakatsuna & 0.09 & 8.0 & 4.3 \\
\hline Keratella quadrata & 1987.4 .30 & Lake Suwa & 0.12 & 10.0 & 3.0 \\
\hline Brachionus calyciflorus & 1987.4 .30 & Lake Suwa & 0.39 & 15.5 & 2.7 \\
\hline \multicolumn{6}{|l|}{ POM } \\
\hline 1-20 $\mu \mathrm{m}$ fraction & 1987.5 .12 & Lake Nakatsuna & - & 4.1 & 3.9 \\
\hline $20-98 \mu \mathrm{m}$ fraction & 1987.5 .12 & Lake Nakatsuna & - & 4.3 & 6.1 \\
\hline 1-3 $\mu \mathrm{m}$ fraction & 1987.4 .30 & Lake Suwa & - & 3.7 & 5.9 \\
\hline $3-20 \mu \mathrm{m}$ fraction & 1987.4 .30 & Lake Suwa & - & 1.7 & 7.0 \\
\hline $20-40 \mu \mathrm{m}$ fraction & 1987.4 .30 & Lake Suwa & - & 4.2 & 6.3 \\
\hline $40-100 \mu \mathrm{m}$ fraction & 1987.4 .30 & Lake Suwa & - & 7.0 & 4.5 \\
\hline
\end{tabular}
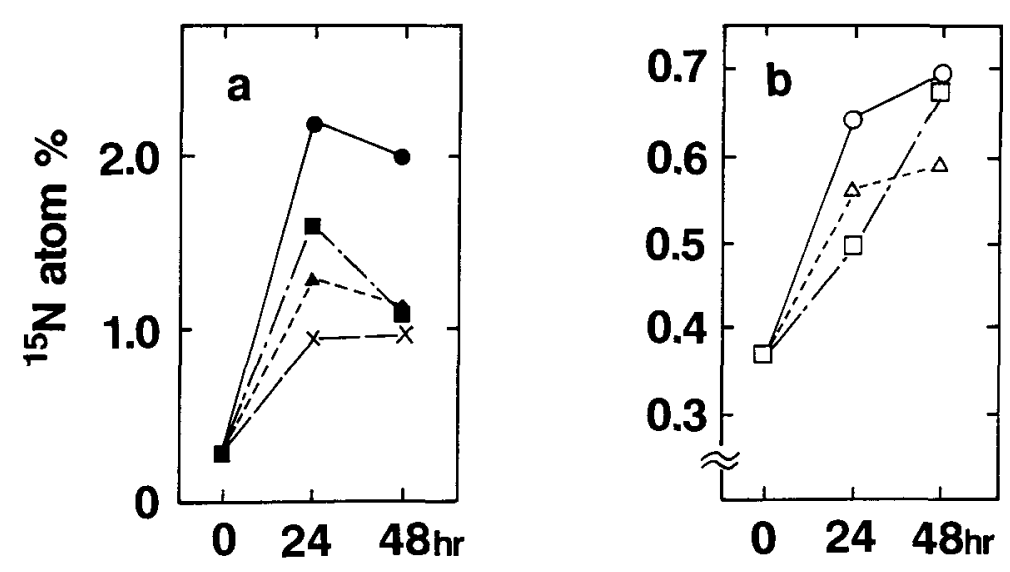

Fig. 3. Changes in ${ }^{15} \mathrm{~N}$ atom \% of POM fractios (a) and zooplankton (b) samples after addition of $\left({ }^{15} \mathrm{NH}_{4}\right)_{2} \mathrm{SO}_{4}$ to lake water from Lake Suwa. In POM samples: "1-3 $\mu \mathrm{m}$ " and "3-20 $\mu \mathrm{m}$ " fractions mainly consisted of Cyclotella sp.; " $20-40 \mu \mathrm{m}$ " made up of Asterionella sp. and Cyclotella sp.; "40-100 $\mu \mathrm{m}$ " of Fragilaria sp., Synedora sp. and some zooplankton (nauplii and small rotifera). Symbols: $\mathbf{\Lambda}, 1-3 \mu \mathrm{m} ; \mathbf{O}, 3-20 \mu \mathrm{m} ; \mathbf{\square}, 20-40 \mu \mathrm{m} ; \times, 40-100$ $\mu \mathrm{m} ; \mathrm{O}$, Keratella quadrata; $\triangle$, Brachionus calyciflons; $\square$, Cyclops vicinus.

Uptake rates for the time period 0 to $24 \mathrm{hr}$ of POM and zooplankton were calculated after Oтsuki (1985) and Otusuki et al. (1987), respectively. POM nitrogen uptake rates in Lake Nakatsuna and Lake Suwa ranged from 2.2 to $6.1 \times 10^{-4}$ and 1.7 to $5.2 \times 10^{-4} \mathrm{mg}$ atom-N $\cdot 1^{-1}$. $\mathrm{day}^{-1}$, respectively (Table 3 ). Ammonium concentration during incubation in Lake Suwa was higher than in Lake Nakatsuna (Table 4). This might reflect the fact that ammonium regeneration (or isotope dilution) was higher in Lake Suwa than in Lake Nakatsuna. It seemed that high ammonium regeneration might be responsible for an underestimation of the nitrogen uptake rates in Lake Suwa.

Nitrogen uptake rates for $K$. longispina in Lake Nakatsuna and for $K$. quadrata in Lake Suwa were $8.5 \times 10^{-8}$ and $4.2 \times 10^{-7} \mathrm{mg}$ atom-N . indiv. ${ }^{-1} \cdot$ day $^{-1}$, respectively (Table 3 ). Relative nitrogen uptake rates per nitrogen content was $16.5 \% \cdot$ day $^{-1}$ for $K$. longispina, and 48.4 $\% \cdot$ day $^{-1}$ for $K$. quadrata. The value implies that $K$. longispina and $K$. quadrata need at least 6 and 2 days, respectively, to double their body 
Table 3. Nitrogen uptake rates of POM fractions, and nitrogen uptake rates and turnover times of zooplankton species. POM and zooplankton nitrogen uptake rates calculated using equations of OTSUKI (1985) and OTSUKI et al. (1987), respectively, for time period 0 to $24 \mathrm{hr}$ in Tracer Experiment. Nitrogen turnover times calculated from nitrogen contents and nitrogen uptake rates.

\begin{tabular}{lllc} 
& Sample name & Sampling lake & $\begin{array}{c}\text { Nitrogen uptake rates } \\
\mathrm{mg} \text { atom- } \cdot \text { indiv. }^{-1} \cdot \text { day }^{-1}\end{array}$ \\
\hline POM & & & - \\
& $1-20 \mu \mathrm{m}$ fraction & Lake Nakatsuna & $\mathrm{N} \cdot 1^{-1} \cdot$ day $^{-1}$ \\
$20-98 \mu \mathrm{m}$ fraction & Lake Nakatsuna & $2.1 \times 10^{-4}$ & - \\
$3-20 \mu \mathrm{m}$ fraction & Lake Suwa & $5.2 \times 10^{-4}$ & - \\
$20-40 \mu \mathrm{m}$ fraction & Lake Suwa & $1.7 \times 10^{-4}$ & \\
& & & $8.5 \times 10^{-8}$ \\
Zooplankton & & - & $4.2 \times 10^{-7}$ \\
Kellicottia longispina & Lake Nakatsuna & - & - \\
Keratella quadrata & Lake Suwa &
\end{tabular}

Table 4. Changes in ammonium concentrations $\left(\mu \mathrm{g}\right.$ atom $\left.-\mathrm{N} \cdot 1^{-1}\right)$ in lake water during incubation.

\begin{tabular}{lccc}
\hline & \multicolumn{3}{c}{ Incubation time } \\
& $0 \mathrm{hr}$ & $24 \mathrm{hr}$ & $48 \mathrm{hr}$ \\
\hline Lake Suwa & 0.97 & 2.48 & 36.7 \\
Lake Nakatsuna & 1.29 & 1.51 & 1.95 \\
\hline
\end{tabular}

nitrogen.

Since the nitrogen uptake rate measured does not include respiration loss and excretion, it approximately corresponded to the net assimilation rate. Net production rates calculated from the nitrogen uptake rates, carbon contents and nitrogen contents (Table 2) in $K$. longispina and $K$. quadrata were $5.1 \times 10^{-6}$ and $2.5 \times 10^{-5} \mathrm{mgC} \cdot$ indiv. $^{-1} \cdot \mathrm{day}^{-1}$, respectively. On the other hand, the rates calculated from body dry weight and environmental temperature after IKEDA and Motoda (1977) were $4.4 \times$ $10^{-6}$ for $K$. longispina and $1.9 \times 10^{-5} \mathrm{mgC}$. indiv. ${ }^{-1} \cdot$ day $^{-1}$ for $K$. quadrata. The net production rates were similar to those calculated from our nitrogen uptake rates, though these estimated values based on different factors. This approximate coincidence suggests that our nitrogen uptake rate is reasonable.

The ${ }^{15} \mathrm{~N}$ atom $\%$ for $0 \mathrm{hr}$ and $24 \mathrm{hr}$ of $K$. longispina was 0.36784 and $0.47440 \%$, respectively. Incubation periods shorter than $24 \mathrm{hr}$ are sufficient to detect changes in ${ }^{15} \mathrm{~N}$ content of small zooklankton, because the analytical variance with alanine addition is less than $0.00106{ }^{15} \mathrm{~N}$ atom \% (see section of Materials and Methods). A detailed knowledge of the feeding habit of small zooplankton may be obtained using this method.

It is important to investigate nitrogen flows not only among the compartments of aquatic ecosystems (e.g. phytoplankton, zooplankton and bacteria) but also with in each compartment among species or individuals. However, nitrogen uptake rates of each species have yet to be examined. We could detect the nitrogen uptake rate of zooplankton at the species level by using the combination of the ratio mass spectrometer and the ${ }^{15} \mathrm{~N}$ tracer experiment. This method can be used to clarify secondary production and strictly measure nitrogen flows in the aquatic food web.

\section{Acknowledgements}

We are indebted to Miss Y. Kabaya for her assistance with ${ }^{15} \mathrm{~N}$ analysis, as well as Dr. T. OKINo and his colleagues at Suwa Hydrobiological Station, Shinshu University for help during the experiment. This study could not have been performed without the generous support of the staff and students of the authors' laboratories. This work was partly supported by a Grant-in-Aid for Special Pro- 
ject Research No. 62124040 from the Ministry of Education, Science and Culture, Japan.

\section{摘要}

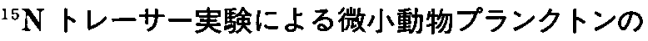 窒素取り込み速度の見積}

窒菜安定同位体 $\left({ }^{15} \mathrm{~N}\right)$ を用いたトレーサー実験 を行い, 淡水のプランクトンの窒素の取り込み速 度を測定した。数 100 個体以下 ( $5 \mu \mathrm{gN}$ 程度) での微小動物プランクトンの微量な ${ }^{15} \mathrm{~N}$ 変化の検出

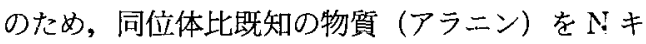
ヤリアーとして用い, 比率直読式質量分析計で測 定を行った。キャリアー添加によって生ずる誤差 は $-0.00210 \sim+0.00113{ }^{15} \mathrm{~N}$ atom \% (平均 $0.00048 \pm 0.0010$ S. D.)の範囲にあった。この方法 で測定を行った結果, 中綱湖の Kellicottia longispinaについて $8.5 \times 10^{-8} \mathrm{mg} \cdot$ atom- $\mathrm{N} \cdot$ indiv. $^{-1}$. day $^{-1}$, 諏訪湖 0 Keratella quadrataについて $4.2 \times 10^{-7} \mathrm{mg} \cdot$ atom $\mathrm{N} \cdot$. $^{2}$ div. $^{-1} \cdot$ day $^{-1}$ の值が得ら れた。取り込み速度, 窒素含量及び炭素含量から 計算した純生産速度は $K$. longispina で $5.1 \times 10^{-6}$ $\mathrm{mgC} \cdot$ indiv $^{-1} \cdot$ day $^{-1}, K$. quadrata $て ゙ 2.5 \times 10^{-5}$ $\mathrm{mgC} \cdot$ indiv $^{-1} \cdot \mathrm{day}^{-1}$ となった。質量分析と ${ }^{15} \mathrm{~N} ト レ$ 一サー実験の組合わせにより，動物プランクトン の種のレベルで, 栄養塩から植物プランクトンを 経た窒素の取り込みが, 同時に, かつ同じ空間で 測定が可能であることが示された。

\section{References}

Bjørnsen, P. K., J. B. Larsen, O. Geertz-Hansen and M. OLSEN (1986): A field technique for the determination of zooplankton grazing on natural bacterioplankton. Freshwater Biology, 16: 245-253.

Bosselmann, S. and B. Riemann (1986): Carbon dynamics in eutrophic, temperate lakes. (ed. Riemann, B. and Søndergaad, M.), 199-236. Elseiver Science Pub., Amsterdam.

Fasham, M. J. R., H. W. Ducklow and S.M. McKelviE (1990): A nitrogen-based model of plankton dynamics in the oceanic mixed layer. Journal of Marine Research, 48: 591-639.

Gilbert, J. J. and K. G. Bogdan (1985): Rotifer grazing: in situ studies on selectivity and rates. American Association for the Advancement of Science. Publ., Westview Press, Inc., Colorado.

HANEY, J. F. (1973): An in situ examination of the grazing activities of natural zooplankton communities. Arch. Hydrobiol., 72: 87-132.
IKEDA, T. and S. MotodA (1977): Estimated zooplankton production and their ammonia excretion in the Kuroshio and Adjacent seas. Fishery Bulletin, 76: 357-367.

Kanda, J., T. SAINo and A. HatToRI (1985): Nitrogen uptake by natural population of phytoplankton and primary production in the Pacific Ocean: regional variability of uptake capacity. Limnol. Oceanogr., 30: 987-999.

LAMPERT, W. (1975): A tracer study on the carbon turnover of Daphnia pulex. Verh. Internat. Verein. Limnol., 19: 2913-2921.

LAMPeRT, W. and W. Gabriel (1984): Tracer kinetics in Daphnia: an improved two-compartment model and experimental test. Arch. Hydrobiol., 100: 1-20.

Minagawa, M., D. A. Winter and I. R. Kaplan (1984): Comparison of Kjeldahl and combustion methods for measurement of nitrogen isotope rates in organic matter. Anal. Chem., 56: 1859-1861.

OTSUKI, A. (1985): An investigation of coupled transformation of ${ }^{13} \mathrm{C},{ }^{15} \mathrm{~N}$ tracer into Lake Kasumigaura. 111-124. Ecology of Microbial, 13. Gakkai Shuppan Center, Tokyo. (in Japanese)

Otsuki, A., M. Aizaki, T. Iwakuma, N. Takamura, M. Hanazato, T. Kawal and M. Yasuno (1985): Coupled transformation of inorganic stable Carbon-13 and Nitrogen-15 isotope higher trophic levels in a eutrophic shallow lake. Limnol. Oceanogr., 32: 820-825.

Otsuki, A., H. Seki, C. D. Mcallister and C. D. LEVINGS (1987): Measurement of net growth rate of herbivorous benthic animals using periphyton labeled simultaneously with ${ }^{13} \mathrm{C}$ and ${ }^{15} \mathrm{~N}$. Limnol. Oceanogr., 32: 499-503.

TAKahashi, M. and Y. SalJo (1981): Nitrogen metabolism in Lake Kizaki, Japan. 1, Ammonium and nitrate uptake by phytoplankton. Arch. Hydrodiol., 91: 393-407.

Technicon Industrial Method (1974): Ammonium in water and seawater. Technicon Industrial methodology. Method No. 154-71 W/B.

Wada, E., T. Tsuji, T. Saino and A. Hattori (1977): A simple procedure for mass spectrometric microanalysis of ${ }^{15} \mathrm{~N}$ in particulate organic matter with special reference to ${ }^{15} \mathrm{~N}$ tracer experiments. Analytical Biochemistry, $80: 312-318$.

Wallace, R. L. and P. L. Starkweather (1985): Clearance rate of sessile rotifer: in vitro determinations. Hydrobiologia, 121: 139-144. 
WATERS, T. F. (1977): Secondary production in inland waters. Adv. Ecol. Res., 10: 91-164.

(著者: 市川忠史*·吉岡崇仁, 信州大学理学部生物 学科, 干 390 長野県松本市旭 3-1-1; 和田英太郎**, 三菱化成生命科学研究所, $\overline{1} 194$ 東京都町田市南大谷 11: 林 秀剛, 信州大学理学部生物学科, $\mathrm{T} 390$ 長野 県松本市旭 3-1-1; *現在, 水産庁中央水産研究所海洋 生産部， $\bar{\top} 104$ 東京都中央区勝どき 5-5-1; **現在, 京都大学生態学研究センター, $7520-01$ 滋賀県大津 市下阪本 4-1-23: Tadafumi IcHIKAWA* and Takahito Yoshioka, Department of Biology, Faculty of Science, Shinshu University, 3-1-1, Asahi, Mat- sumoto 390; Eitaro WADA**, Mitsubishi-Kasei Institute of Life Sciences, 11, Minamiooya, Machida, Tokyo 190; Hidetake HayashI, Department of Biology, Faculty of Science, Shinshu University, 31-1, Asahi, Matsumoto 390; *Present address: Marine Productivity Division, National Research Institute of Fisheries Science, 5-5-1, Kachidoki, Chuo-ku, Tokyo 104; ${ }^{* *}$ Present address: Center for Ecological Research, Kyoto University, 4-1-23, Shimosakamoto, Otsu 520-01)

Received: 10 June 1991

Accepted: 6 May 1992 